\title{
In vitro selection and characterization of drought-tolerant plants of durum wheat (Triticum durum Desf)
}

\author{
D Hsissou, J Bouharmont * \\ Laboratory of Cytogenetics, Department of Biology, Université Catholique de Louvain, \\ Place Croix du Sud, 5, Bte 13, B1348 Louvain-la-Neuve, Belgium \\ (Received 7 July 1993; accepted 4 January 1994)
}

\begin{abstract}
Summary - Somaclonal variation has been used as a source of variability to improve the drought tolerance of durum wheat (Triticum durum Desf). Of the 6 varieties currently grown in Morocco, 3 were selected for their ability to produce calli and regenerate plants in vitro. Using polyethylene glycol 10000 in the in vitro culture medium, low external water potentials were applied during callus proliferation and plant regeneration phases to select plantlets that were tolerant to drought. Out of the 30 plants that survived the stress, 13 exhibited improved tolerance to drought compared with unselected controls, using chlorophyll fluorescence and electrolyte leakage of leaves subjected to water stress as criteria. Applying osmotic stress during the regeneration phase seemed to be the most efficient.
\end{abstract}

durum wheat / in vitro selection / drought tolerance / PEG

Résumé - Sélection in vitro et caractérisation de plantes de blé dur (Triticum durum Desf) tolérantes à la sécheresse. La variation somaclonale a été utilisée comme source de variation génétique pour l'amélioration de la tolérance à la sécheresse chez le blé dur (Triticum durum Desf). Parmi 6 variétés largement cultivées au Maroc, 3 ont été choisies sur leur capacité à développer des cals et à régénérer des plantes in vitro. L'addition de polyéthylène glycol 10000 aux milieux de culture a été utilisée pour réduire le potentiel hydrique externe, pendant la croissance des cals ou durant la phase de régénération, et sélectionner des plantules tolérantes à la sécheresse. Sur les 30 plantules régénérées à partir des cals survivants, 13 montrent une amélioration de la tolérance par rapport aux témoins, sur la base des mesures de la fluorescence de la chlorophylle et des pertes d'électrolytes effectuées sur les feuilles en présence d'un stress hydrique. La sélection sur milieu de régénération semble la plus efficace.

blé dur / sélection in vitro / tolérance à la séchesse / PEG

\section{INTRODUCTION}

Drought affects approximately $40 \%$ of the cultivated land throughout the world, reducing markedly crop yield (Oertli, 1983). In wheat, water stress influences all phases of devel- opment from germination up to grain filling, through vegetative and reproductive growth. Owing to the fact that this species, which is of great economic importance, has to endure drought conditions in numerous countries where it is cultivated, its future production will largely depend on studies devoted to a better understanding of this stress.

\footnotetext{
* Correspondence and reprints.
} 
Improved field techniques, particularly the use of irrigation, resulted in a lessening of the detrimental effects of water deficit. When irrigation is unfeasible, however, genetic improvement probably remains a choice method for obtaining plant material capable of satisfactory production under drought conditions.

The aim of our study was to exploit in vitro techniques for production, selection, and regeneration of durum wheat somaclonal mutants that are tolerant to drought. The stress was induced by adding high molecular weight polyethylene glycol (PEG) to the culture medium. In vitro selection using PEG as an osmotic agent allowed the regeneration of plant lines tolerant to drought in various species including tomato, rice and tobacco (Heyser and Nabors, 1979; Bressan et al, 1981, 1982; Kishor and Reddy, 1984; Sumaryati et al, 1992). Chlorophyll fluorescence and electrolyte leakage served as indicators of drought tolerance (Havaux et al, 1988; Vasquez-Tello et al, 1990).

\section{MATERIALS AND METHODS}

\section{Plant material}

Six varieties (Kypérounda (2777), Sebou (1715), Selbéra (272), E21, E15 and Massa (1728)) were provided by the INRA from Morocco and were tested for their in vitro potentialities. The first 3 were selected for the present study because they were able to produce calli and plantlets at high rates.

Mature embryos were used as explants. The caryopses were surface sterilized first using ethanol $(94 \%)$ for $10 \mathrm{~s}$ followed by formaldehyde $(0.75 \%)$ for $40 \mathrm{~min}$ with continuous shaking, and $\mathrm{Ca}(\mathrm{ClO})_{2}(5 \%)$ for $20 \mathrm{~min}$. They were then rinsed 3 times with sterile water before being incubated in Petri dishes on Whatman paper imbibed with sterile water.

After a $24 \mathrm{~h}$ pre-germination period under a $12 \mathrm{~h}$ light $/ 12 \mathrm{~h}$ dark cycle at $25^{\circ} / 20^{\circ} \mathrm{C}$ (day/night), the embryos were excised and transferred, scutellar side up, to the callogenesis medium.

\section{Culture media}

Two basic culture media were used: MS (Murashige and Skoog, 1962) and LS (Linsmaier and Skoog, 1965). Growth factors added to induce callogenesis and support callus development were $0.495 \mathrm{mg} / \mathrm{l}$ 2,4-D-2,4-dichlorophenoxyacetic acid,
$1 \mathrm{mg} / \mathrm{l}$ naphthaleneacetic acid (NAA) and $1 \mathrm{mg} / \mathrm{l}$ benzylaminopurine (BAP). Two regeneration media were used ( $\mathrm{R} 1$ and R2); R1 (for Kypéroun$\mathrm{da}$ and Sebou) was based on the LS mineral elements at half-concentration for macronutrients, with $1 \mathrm{mg} / \mathrm{l} \mathrm{BAP}, 1 \mathrm{mg} / \mathrm{l} \mathrm{NAA}$ and $1.5 \%$ sucrose, and R2 (for Selberra) contained the MS elements at half-concentration for macroélements, $10.75 \mathrm{mg} / \mathrm{l}$ kinetin, $1.752 \mathrm{mg} / \mathrm{l}$ indoleacetic acid (IAA) and $3 \%$ sucrose. After regeneration, the plantlets were transferred to a regeneration medium with $1 \mathrm{mg} / \mathrm{I}$ IAA for rooting.

Polyethyleneglycol 10000 (PEG), which is a non-toxic hydrosoluble polymer, is used in the in vitro culture medium for drought-resistance selection. PEG simulates water stress by reducing the free water in the extracellular medium and the water available to the cells.

\section{Evaluation of drought tolerance}

After regeneration, rooted plantlets were washed, planted in pots and cultivated in a growth room with a day length of $12 \mathrm{~h}$; the temperature was $30^{\circ} \mathrm{C}$ during the day and $25^{\circ} \mathrm{C}$ during the night. The light intensity was about $200 \mu \mathrm{E} \cdot \mathrm{m}^{-2} \cdot \mathrm{s}^{-1}$ and the relative humidity $90 \%$. The plants received modified Hoagland solution (Gulick and Dvorak, 1987) every $10 \mathrm{~d}$.

Chlorophyll fluorescence and electrolyte leakage, which are usually considered as appropriate tests for drought-tolerance evaluation (Havaux and Lannoye, 1985; Havaux et al, 1988; Martin et al, 1987, Vasquez-Tello et al, 1990), were used to estimate the response of the regenerated plants to water stress and to compare these plants to unselected genotypes. The stress was applied to the youngest completely unfolded leaf of plantlets with 3-4 leaves by placing leaf segments on a filter paper, in a Petri dish, for $6 \mathrm{~h}$, in the dark and at $25^{\circ} \mathrm{C}$.

The technique used for measuring the chlorophyll fluorescence has been described by Havaux and Lannoye (1985) and Havaux et al (1988). The portable Hansatech fluorimeter gives an estimation of the efficiency of primary photochemical processes of PSIl based on the ratio between variable and maximum fluorescence $\left(F_{v} / F_{m}\right)$. Three readings were recorded for each sample; the mean value was then compared to the ratio obtained for unstressed leaves.

To measure the electrolyte leakage, the segments of the young unfolded leaf were divided into 3 batches in order to get 3 replications. The fragments were thoroughly washed to remove all electrolytes from their surface and from the wounded parts (Blum and Ebercon, 1981). After desiccation of the samples, the proportion of electrolytes released in the water was estimated by conductimetry, according to Martin et al (1987). 


\section{RESULTS \\ Determination of stress conditions for selection}

PEG concentration and stress duration must be sufficient to prevent the growth of original cells but to allow the proliferation of tolerant cells. Three PEG concentrations (15, 20 and $25 \%$ ) were tested and compared with the standard culture media. Thirty 36-day-old calli were grown for each PEG concentration and variety. The weight of the calli was determined before treatment and at each monthly transfer for 6 months. In order to reduce the effect of initial weight on the growth rate, the inoculated calli had similar weights for all varieties. The growth of the calli as a function of duration of the PEG treatment is illustrated in figure 1. For the 3 varieties, callus growth was significantly reduced by the presence of PEG from the first month onward. The stress effect increased with PEG concentration. The growth was almost stopped after 6 months for the highest PEG concentrations, which appeared to be the most suitable for selection.

Based on these preliminary observations, we elaborated 3 different stress procedures for drought-resistance selection: (i) the calli were cultured on a solid medium with PEG $(25 \%)$ for 6 months; (ii) the selection was performed during the regeneration phase by growing calli for 2 months on the R1 or R2 media containing PEG 25\%; and (iii) a shorter selection period (30 d) was used for growing calli in a liquid medium (LS) with PEG $35 \%$ before regeneration.

\section{In vitro selection and plant regeneration}

When grown under stress conditions, most calli became necrotic and many of them died, but some cell groups remained able to grow and to regenerate plantlets. While untreated calli often gave 3-4 plantlets, only one appeared on the most stressed calli.

For the first selection procedure, $3500 \mathrm{em}$ bryos from each of the 3 varieties were cultured on callus-inducing medium for 1 month before being transferred to the selective medium for 6 months. At the end of the selection
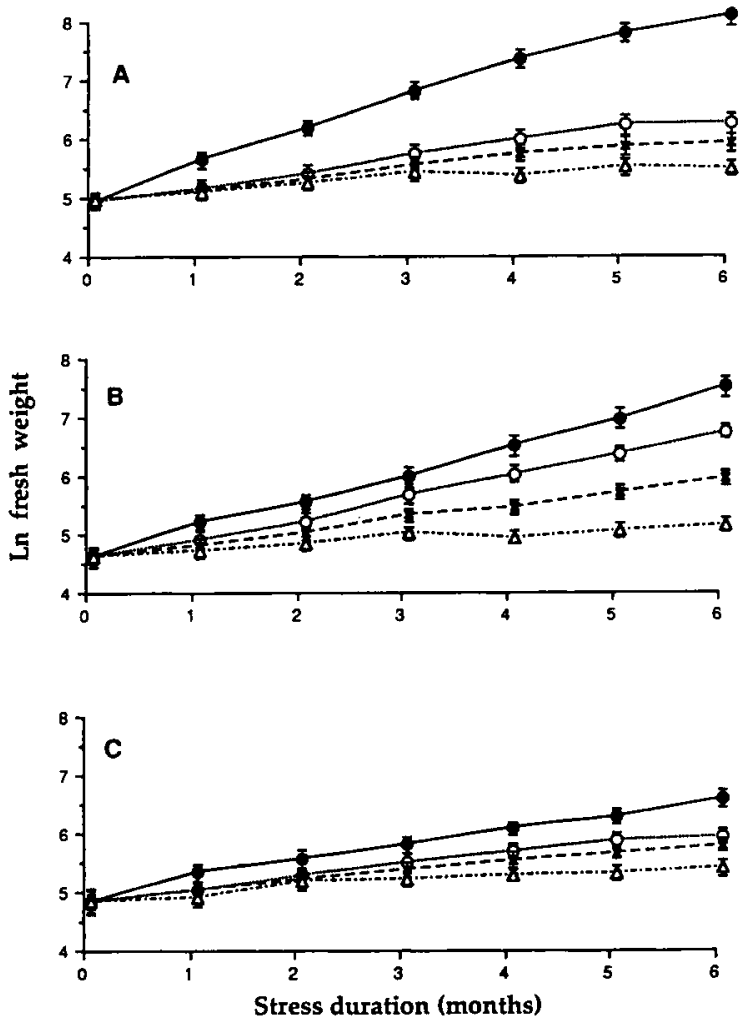

Fig 1. The effect of PEG on callus growth as a function of the stress duration in (A) Kypérounda, (B) Sebou, and (C) Selbéra. PEG concentrations: $=0 \%, O=15 \%, x$ $=20 \%$, and $\Delta=25 \%$. Data are given as mean $\pm S D$.

pressure, the non-necrotic calli were transferred to the regeneration medium where 2 Kypérounda, 5 Sebou and 4 Selbéra plants were recovered after 2 months. These plants are referred to as RoS.

For selection applied at the regeneration stage, 1000 embryos per variety were cultured during 1 month on the induction medium before being transferred to the regeneration medium containing PEG. After 2 months, 3 Kypérounda, 5 Sebou and 5 Selbéra plants were obtained. These plants are referred to as RoR.

For the third selection method, $1000 \mathrm{em}$ bryos per variety were cultured for 1 month on the induction solid medium before being transferred for 1 month further to the liquid medium containing PEG. The calli were then kept for 2 months on the regeneration medium where 2 Kypérounda and 3 Sebou plants were produced. These plants are referred to as RoL.

The 30 plants regenerated on selective media were grown up to maturity. 


\section{Estimation of drought tolerance of regenerated plants}

Chlorophyll fluorescence and electrolyte leakage were measured for dehydrated leaf samples of the plants regenerated from the cellular lines selected for their drought tolerance. The results are shown in 3 separate tables for the plants issued from each of the 3 Moroccan parental lines (tables I, II, III). They indicate that 13 individuals (5 Kypérounda, 5 Sebou and 3 Selbera) out of the 30 plants tested exhibited an improved tolerance in comparison to the parental genotypes. The data from chlorophyll fluorescence and electrolyte leakage were consistent.

Table I. Chlorophyll fluorescence and electrolyte leakage in Kypérounda plants selected for their resistance to drought, as influenced by a 6-h dehydration stress applied to leaf samples.

\begin{tabular}{lcc}
\hline \multicolumn{1}{c}{ Plant } & $\begin{array}{c}\mathrm{Fv}^{\prime} \mathrm{F}_{m}(\% \text { of } \\
\text { non-stressed control) }\end{array}$ & $\begin{array}{c}\text { Electrolyte leakage } \\
\text { (\% of total) }\end{array}$ \\
\hline Unselected plant from the parent genotype & $48.74 \pm 5.21$ & $70.88 \pm 7.91$ \\
RoS1 & $50.00 \pm 4.32$ & $71.14 \pm 5.69$ \\
RoS2 & $59.00 \pm 3.25^{\star}$ & $61.89 \pm 6.42^{*}$ \\
RoR1 & $49.00 \pm 2.56$ & $70.00 \pm 5.89$ \\
RoR2 & $47.00 \pm 3.89$ & $71.00 \pm 8.12$ \\
RoR3 & $80.00 \pm 4.58^{*}$ & $59.2 \pm 5.99^{\star}$ \\
RoR4 & $87.00 \pm 6.12^{*}$ & $62.19 \pm 4.78^{*}$ \\
RoL1 & $67.00 \pm 7.15^{*}$ & $61.68 \pm 6.89^{\star}$ \\
RoL2 & $61.00 \pm 6.56^{*}$ & $64.01 \pm 5.96^{*}$ \\
\hline
\end{tabular}

Data are given as mean $\pm S D$; ${ }^{*}$ plants that are statistically different from unselected plants using Fisher's test at a $95 \%$ probability level.

Table II. Chlorophyll fluorescence and electrolyte leakage in Sebou plants selected for their resistance to drought, as influenced by a 6 -h dehydration stress applied to leaf samples.

\begin{tabular}{lcc}
\hline \multicolumn{1}{c}{ Plant } & $\begin{array}{c}F_{V} / F_{m}(\% \text { of } \\
\text { non-stressed control) }\end{array}$ & $\begin{array}{c}\text { Electrolyte leakage } \\
\text { (\% of total) }\end{array}$ \\
\cline { 2 - 3 } Unselected plant from the parent genotype & $59.95 \pm 3.89$ & $79.21 \pm 6.14$ \\
RoS1 & $47.75 \pm 5.78$ & $78.49 \pm 5.89$ \\
RoS2 & $62.25 \pm 6.14$ & $81.89 \pm 7.45$ \\
RoS3 & $50.75 \pm 5.66$ & $80.51 \pm 8.23$ \\
RoS4 & $80.37 \pm 6.97^{\star}$ & $60.00 \pm 7.02^{\star}$ \\
RoS5 & $51.00 \pm 4.13$ & $79.15 \pm 6.15$ \\
RoR1 & $76.87 \pm 4.68^{\star}$ & $68.32 \pm 5.78^{\star}$ \\
RoR2 & $68.12 \pm 7.15^{\star}$ & $68.06 \pm 7.03^{*}$ \\
RoR3 & $72.13 \pm 5.57^{\star}$ & $63.59 \pm 4.86^{\star}$ \\
RoR4 & $52.12 \pm 5.36$ & $79.56 \pm 5.15$ \\
RoR5 & $54.50 \pm 4.65$ & $78.26 \pm 4.79$ \\
RoL1 & $49.50 \pm 3.26$ & $81.09 \pm 8.06$ \\
RoL2 & $56.15 \pm 2.98$ & $72.98 \pm 4.64$ \\
RoL3 & $56.15 \pm 4.65^{\star}$ & $60.07 \pm 5.66^{*}$ \\
\hline
\end{tabular}

Data are given as mean $\pm \mathrm{SD}$; "plants that are statistically different from unselected plants using Fisher's test at a $95 \%$ probability level. 
Table III. Chlorophyll fluorescence and electrolyte leakage in Selbéra plants selected for their resistance to drought, as influenced by a $6-\mathrm{h}$ dehydration stress applied to leaf samples.

\begin{tabular}{lcc}
\hline \multicolumn{1}{c}{ Plant } & $\begin{array}{c}\mathrm{F}_{v} / \mathrm{F}_{m}(\% \text { of } \\
\text { non-stressed control) }\end{array}$ & $\begin{array}{c}\text { Electrolyte leakage } \\
\text { (\% of total) }\end{array}$ \\
\hline Unselected plant from the parent genotype & $62.24 \pm 6.11$ & $74.25 \pm 8.17$ \\
RoS1 & $62.75 \pm 2.44$ & $76.25 \pm 5.29$ \\
RoS2 & $61.87 \pm 2.25$ & $78.68 \pm 4.05$ \\
RoS3 & $63.00 \pm 5.33$ & $67.95 \pm 7.11$ \\
RoS4 & $71.37 \pm 6.01^{*}$ & $60.57 \pm 4.45^{*}$ \\
RoR1 & $60.00 \pm 4.13$ & $76.50 \pm 4.66$ \\
RoR2 & $61.87 \pm 4.11$ & $74.40 \pm 6.30$ \\
RoR3 & $63.00 \pm 3.14$ & $73.25 \pm 7.33$ \\
RoR4 & $72.50 \pm 3.99^{*}$ & $66.00 \pm 5.44^{*}$ \\
RoR5 & $70.00 \pm 4.09^{*}$ & $64.95 \pm 6.15^{*}$ \\
\hline
\end{tabular}

Data are given as mean \pm SD; * plants that are statistically different from unselected plants using Fisher's test at a $95 \%$ probability level.

\section{CONCLUSIONS}

Using chlorophyll fluorescence and electrolyte leakage as indicator tests, improved drought-tolerant plants were regenerated after selection on culture media containing PEG. Since these physiological tests, especially electrolyte leakage, are sometimes considered to provide a measure of membrane integrity (Martin et al, 1987; Vasquez-Tello et al, 1990), it could be suggested that the selected character is related to a modification of the properties of the cell membranes that are able to keep their integrity in the presence of water stress. The stability and the heredity of this selected character remain, however, to be established since transient, not heritable, physiological adaptations of cells grown under stress conditions may occur (Demarly, 1986). This phenomenon could also account for the plants regenerated from selected calli that did not differ significantly from the original genotypes. The heterogeneity of the plant populations frequently recovered after in vitro selection (Dix, 1977) could also be due to the persistence of some original non-mutated cells in the selected calli (Demarly, 1986).

According to Nabors et al (1980), the presence of a selective agent in the regeneration medium can increase the probability of recovering tolerant plants. In this way, $\mathrm{NaCl}$ tolerant plants have been obtained in Oryza sativa (Li and Heszki, 1986) and Kickxia ramosissma (Mathur et al, 1980). In our experiments, the 3 selection procedures have been successful, but it seems that the application of the osmotic stress during the regeneration phase was the most efficient: 7 plants showing an improved tolerance were obtained with such a treatment and only 3 for each of the other methods.

The progeny of the selected plants is currently under study to establish whether the selected character is stable and heritable.

\section{ACKNOWLEDGMENT}

This research was supported by the UREF (Project No 91027 'Biotechnologies pour l'adaptation des céréales à l'aridité et à la salinité').

\section{REFERENCES}

Blum A, Ebercon A (1981) Cell membrane stability as a measure of drought and heat tolerance in wheat. Crop Sci 21, 43-47

Bressan RA, Hasegawa PM, Handa AK (1981) Resistance of cultured higher plant cells to polyethylene glycol-induced water stress. Plant Sci Lett 21, 23-30

Bressan RA, Handa AK, Handa S, Hasegawa PM (1982) Growth and water relation characteristics of cultured tomato cells during adjustement 
to low external water potentials. Plant Physiol $70,1303-1309$

Demarly $Y$ (1986) Experimental and theoretical approach of in vitro variations. In: Somaclonal Variations and Crop Improvement. (J Semal, ed) Martinus Nijoff Publishers, Dordrecht, the Netherlands, 83-99

Dix PJ (1977) Chilling resistance is not transmitted sexually in plants regenerated from $\mathrm{Ni}$ cotiana sylvestris cell lines. Z Pflanzenphysiol 84, 223-226

Gulick P, Dvorak J (1987) Gene induction and repression by salt treatment in roots of the salinity-sensitive chinese spring wheat and the salinity-tolerant chinese spring $x$ Elytrigia amphiploid. Proc Natl Acad Sci USA 48, 99-103

Havaux M, Lannoye R (1985) In vivo chlorophyll fluorescence and delayed light emission as rapid screening techniques for stress tolerance in crop plants. Z Pflanzenzüchtg 95, 1-13

Havaux M, Ernez M, Lannoye R (1988) Sélection de variétés de blé dur (Triticum durum Desf) et de blé tendre (Triticum aestivum $\mathrm{L}$ ) adaptées à la sécheresse par la mesure de l'extinction de la fluorescence de la chlorophylle, agronomie 8, 193-199

Heyser JW, Nabors MW (1979) Osmotic adjustment of tobacco cells and plants to penetrating and non-penetrating solutes. Plant Physiol 63, 5-77

Kishor PBK, Reddy GM (1965) Organic growth factor requirements of tissue culture. Physiol Plant 18, 100-127
Li Su N, Heszki LE (1986) Testing of salt $\mathrm{NaCl}$ tolerance and regeneration in callus cultures. In: Genetic Manipulations in Plant Breeding (W Horn, CJ Jensen, W Oldenbach, O Schieder, eds) de Gruyter, Berlin 617-619

Martin U, Pallardry SG, Bahari ZA (1987) Dehydration tolerance of leaf tissues of six woody angiosperm species. Physiol Plant 69, 182-186

Mathur AK, Ganapathy PS, Johri BM (1980) Isolation of sodium chloride-tolerant plantlets of Kickxia ramosissma under in vitro conditions. Z Pflanzenphysiol 99, 287-294

Murashige T, Skoog F (1962) A revised medium for rapid growth and bioassays with tobacco tissue cultures. Physiol Plant 15, 473-479

Nabors MW, Gibbs SE, Berntsein CS, Meis ME (1980) NaCl-tolerant tobacco plants from cultured cells. Z Pflanzenphysiol 97, 13-17

Oertli JJ (1983) Adaptation of plants to limited water availability. In: Nutrient Balances and the Need for Fertilizer in Semi-Arid Zones. Proc 17th Colloq Intern Potash Institute Bern, 394

Sumaryati S, Negrutiu I, Jacobs M (1992) Characterisation and regeneration of salt and water stress mutants from protoplast culture of Nicotiana plumbaginifolia. Theor Appl Genet 83, 613-619

Vasquez-Tello A, Zuily-Fodil Y, Pham Thi AT, Vieira Da Silva JB (1990) Electrolyte and Pi leakages and soluble sugar content as physiological tests for screening resistance to water stress in Phaseolus and Vigna species. J Exp Bot $228,827-832$ 